
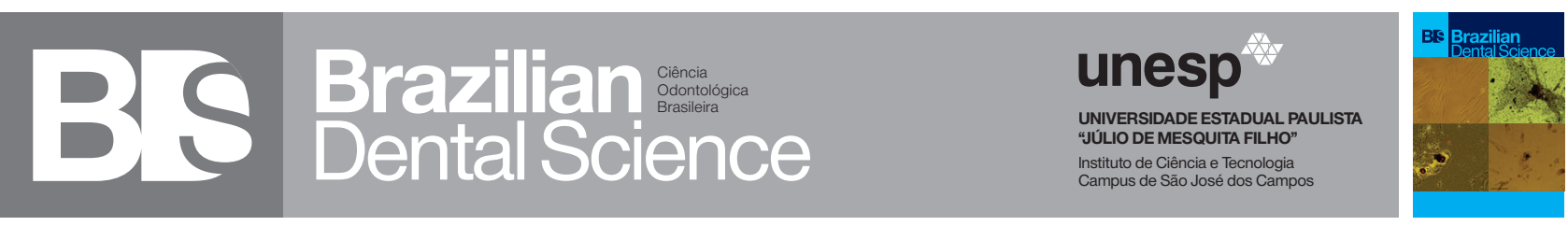

\title{
Clinical performance of whitening on devitalized teeth: a retrospective observational study
}

Desempenho clínico do clareamento em dentes desvitalizados: estudo observacional retrospectivo

Ayla Macyelle de Oliveira CORREIA ${ }^{1}$, Felipe de Souza MATOS ${ }^{1}$, Maria Filomena Rocha Lima HUHTALA ${ }^{1}$, Eduardo BRESCIANI ${ }^{1}$, Taciana Marco Ferraz CANEPPELE ${ }^{1}$

1 - São Paulo State University (Unesp) - Institute of Science and Technology, São José dos Campos - Department of Restorative Dentistry - São José dos Campos - SP - Brazil.

\begin{abstract}
Objective: This retrospective observational study evaluated the clinical performance of intracoronal whitening and correlated the main factors that interfere with its stability and patient satisfaction. Material and Methods: The paper was designed following the STROBE statement. Patients from the Institute of Science and Technology - ICT/UNESP database who underwent nonvital tooth whitening from August 2010 to July 2015 were selected. Data collection was performed by researching the institution records, patients interview, clinical and radiographic examination. Data were analyzed using MannWhitney test and Spearman's correlation ( $\mathrm{p}<0.05)$. Results: The initial search on 1275 records resulted in 43 patients, of whom 18 were selected according to eligibility criteria. There was positive correlation only between the degree of patient's satisfaction and the perception of color difference after whitening treatment $(\mathrm{p}<0.05)$. Color relapse was observed in all conditions, independently of the period of followup ( $\mathrm{p}>0.05$ ). There was no case of external cervical root resorption. Conclusion: Color changes after whitening influenced patient's satisfaction. There was no correlation among the color relapse and height of gutta-percha, return interval or cause of darkening.
\end{abstract}

\section{KEYWORDS}

Tooth discoloration; Tooth nonvital; Tooth whitening.

\section{RESUMO}

Objetivo: Este estudo observacional retrospectivo avaliou o desempenho clínico do clareamento interno e correlacionou os principais fatores que interferem em sua estabilidade e satisfação do paciente. Material e Métodos: O artigo foi elaborado seguindo o STROBE. Pacientes do banco de dados do Instituto de Ciência e Tecnologia - ICT/UNESP que foram submetidos ao clareamento dental em dentes desvitalizados entre agosto de 2010 e julho de 2015 foram selecionados. A coleta de dados foi realizada por meio de pesquisa em prontuários da instituição, entrevista com os pacientes, exames clínico e radiográfico. Os dados foram analisados usando o teste de Mann-Whitney e correlação de Spearman ( $\mathrm{p}<0,05$ ). Resultados: A pesquisa inicial em 1275 registros resultou em 43 pacientes, dos quais 18 foram selecionados de acordo com os critérios de elegibilidade. Houve correlação positiva apenas entre o grau de satisfação do paciente e a percepção da diferença de cor após o tratamento clareador $(\mathrm{p}<0,05)$. A recidiva da cor foi observada em todas as condições, independentemente do tempo de acompanhamento $(\mathrm{p}>0,05)$. Não houve nenhum caso de reabsorção cervical externa. Conclusão: As mudanças de cor após o clareamento influenciaram a satisfação do paciente. Não houve correlação entre a recidiva da cor e a altura do guta-percha, o intervalo de retorno ou a causa do escurecimento.

\section{PALAVRAS-CHAVE}

Descoloração de dente; Dente não vital; Clareamento dental. 


\section{INTRODUCTION}

$\mathrm{T}$ ooth discoloration has been pointed out as one of the leading causes of patients' esthetic unsatisfaction [1-3]. Changes in tooth color may occur due to pathophysiological processes or to external factors, such as intake of dietary sources that have dark pigments (wine, coffee, tea), which cause intrinsic and extrinsic enamel or dentin stains $[4,5]$. Other factors such as pulpal necrosis, trauma, and iatrogenic endodontic treatments have also been reported as the main causes of tooth discoloration [6-8]. The correct diagnosis of the cause of tooth discoloration is of great importance, as it influences the choice and outcome of the treatment [5].

Intracoronal whitening is a conservative alternative for the esthetic treatment of nonvital teeth [5]. In this treatment, two whitening techniques are proposed: the inside-outside technique, which carbamide peroxide and hydrogen peroxide agents are used in low concentrations [9], and the walking bleaching technique [10], where association of sodium perborate and hydrogen peroxide is employed in the pulp chamber, with weekly changes until a satisfactory tooth color was achieved. However, these treatments can cause alterations in the enamel, dentin and cement surface structure, decreasing the microhardness, changing the chemical composition of enamel and dentin and external root resorption $[5,11,12]$.

The recurrence of intracoronal whitening has been reported in the literature by several authors [13-15]. The variations in clinical research results that have evaluated the effectiveness of intracoronal whitening may be due to insufficient numbers of cases, different techniques, and final restorations, as well as different definitions of color relapse. The chemical reduction of oxidation products, the marginal breakdown of the final restoration and the permeability of enamel and dentin to extrinsic substances are considered the possible causes of color relapse [16]. However, there are no studies evaluating the clinical performance of the whitening treatment and the main factors that interfere with its stability.
Given the importance of longevity of nonvital teeth whitening and the factors that interfere in the treatment result as the cause of discoloration, the whitening technique used and patient habits, the aim of this study was to evaluate the clinical performance of the whitening treatment in nonvital teeth using the walking bleaching technique and inside-outside technique, correlating the main factors that may interfere in the stability of the whitening and patient satisfaction.

\section{MATERIAL AND METHODS}

\section{Study design}

This research was developed in the retrospective observational study model and followed the Strengthening the Reporting of Observational Studies in Epidemiology (STROBE) statement (https://www.strobestatement.org). Patients were reviewed within 1 to 5 years after intracoronal whitening to assess the clinical performance of the treatment. The protocol of the study was approved by the local Institute Review Board (CAAE: 59338016.0.0000.007), and all the volunteer patients signed an informed consent form.

\section{Patient selection}

One thousand two hundred and seventyfour patients who were treated at School of Dentistry at Institute of Science and Technology of São José dos Campos, São Paulo, Brazil, were initially screened for the study using the institution's records. Patients older than 18 years old and who underwent intracoronal whitening treatment from August 2010 to July 2015 were included in the study.

The participants were recruited over a 5-month period from August to December 2016. After a full general and dental examination, patients with intellectual disability or whose tooth was unavailable for evaluation due to a fixed prosthesis, caries, poor restoration, cracking, or fracture, were excluded.

\section{Data collection}

Data collection was performed by 
researching records of the Institution, by interviewing the patients and by clinical/ radiographic examination.

A structured questionnaire with 15 objective questions was individually applied to the participants by a previously trained examiner, with an estimated time of 20 minutes for each interview. The questionnaire included sociodemographic characteristics (gender, age, and educational level), oral hygiene habits (frequency of dental brushing and flossing), consumption patterns (coffee or soft drinks and smoke), the esthetic perception of color stability, and degree of satisfaction with the result of the whitening treatment.

Institution records were consulted to obtain information such as the cause of darkening and presence of external cervical resorption before tooth whitening, the whitening technique employed, and period of treatment. The clinical and radiographic examination was performed to evaluate the type and position of the tooth, the presence of external cervical resorption, and the height of gutta-percha in the cervical third of root canal by a second examiner. The height of gutta-percha was considered appropriate when located at least $2 \mathrm{~mm}$ below the root canal orifice or the cementoenamel junction.

\section{Data analysis}

Data obtained from the application of structured questionnaires, institution's records and clinical/radiographic examination were tabulated and analyzed by descriptive statistics using absolute(n) and relative (\%) frequencies. To infer whether there was a correlation between the factors height of gutta-percha, return interval, the cause of darkening and degree of patient satisfaction with the color stability of the bleached tooth, data were analyzed by the Mann-Whitney test and Spearman correlation $(\mathrm{p}<0.05)$.

\section{RESULTS}

One thousand two hundred and seventyfour records of patients were initially screened for the study, but 1231 not meeting the inclusion criteria and 25 declining participation were excluded (Figure 1). Thus, 18 patients were analyzed for the clinical performance of intracoronal whitening. Four patients were male $(22 \%)$, and 14 were female $(78 \%)$. The age of patients ranged from 18-59 years old (mean age of 45 years). Table 1 shows patients demographics.

The sodium perborate and water were used in patients who have undergone bleaching of nonvital teeth by the walking bleaching technique, while $35 \%$ hydrogen peroxide, sodium perborate and water were used in inside-outside technique. The whitening agents were applied is for up to four weeks.

The distribution of teeth included in the study and the factors related to the clinical performance of whitening treatment are summarized in table 2 . The criteria assessed during the visit of patients are listed in table 3.

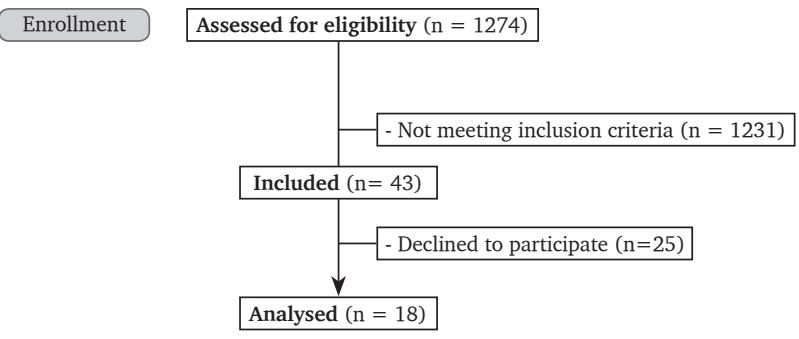

Figure 1- Flow diagram of the retrospective study.

Table 1 - General characteristics of the patients included in the study

\begin{tabular}{|c|c|c|}
\hline \multicolumn{2}{|c|}{ Characteristics } & $\mathbf{n}$ \\
\hline \multirow{2}{*}{ Gender } & Male & 4 \\
\hline & Female & 14 \\
\hline \multirow{2}{*}{ Age } & $18-40$ years old & 5 \\
\hline & 41-60 years old & 13 \\
\hline \multirow{3}{*}{ Educational level } & Basic education & 6 \\
\hline & High school & 9 \\
\hline & Higher education & 3 \\
\hline \multirow{2}{*}{ Coffee or soft drinks } & Yes & 17 \\
\hline & No & 1 \\
\hline \multirow{2}{*}{ Smoke } & Yes & 2 \\
\hline & No & 16 \\
\hline
\end{tabular}


Table 2 - Distribution of teeth included in the study and factors related to the clinical performance of whitening treatment

\begin{tabular}{|c|c|c|}
\hline \multicolumn{2}{|c|}{ Characteristics } & $\mathrm{n}$ \\
\hline \multirow{3}{*}{ Type of tooth } & Central incisor & 10 \\
\hline & Lateral incisor & 5 \\
\hline & Canine & 3 \\
\hline \multirow{2}{*}{ Position } & Maxillary & 18 \\
\hline & Mandibular & 0 \\
\hline \multirow{3}{*}{$\begin{array}{l}\text { Cause of darkening before } \\
\text { tooth whitening }\end{array}$} & latrogenic & 12 \\
\hline & Necrosis & 4 \\
\hline & Trauma & 2 \\
\hline \multirow{2}{*}{ Whitening technique } & Walking & 12 \\
\hline & Inside-outside & 6 \\
\hline \multirow{2}{*}{$\begin{array}{l}\text { Return interval after tooth } \\
\text { whitening }\end{array}$} & $1-2$ years & 11 \\
\hline & $3-5$ years & 7 \\
\hline
\end{tabular}

Table 3 - Criteria assessed during the visit of the patients

\begin{tabular}{|cccccc|} 
\#ID & Age & $\begin{array}{c}\text { External } \\
\text { cervical } \\
\text { resorption }\end{array}$ & $\begin{array}{c}\text { Height } \\
\text { of gutta- } \\
\text { percha }\end{array}$ & $\begin{array}{c}\text { Patient's } \\
\text { satisfaction }\end{array}$ & $\begin{array}{c}\text { Color } \\
\text { stability }\end{array}$ \\
\hline 1 & 54 & No & Appropriate & Satisfied & Yes \\
\hline 2 & 47 & No & Inappropriate & Unsatisfied & No \\
\hline 3 & 42 & No & Inappropriate & Unsatisfied & No \\
\hline 4 & 47 & No & Appropriate & Unsatisfied & No \\
\hline 5 & 59 & No & Inappropriate & Satisfied & Yes \\
\hline 6 & 59 & No & Inappropriate & Satisfied & Yes \\
\hline 7 & 38 & No & Appropriate & Unsatisfied & No \\
\hline 8 & 50 & No & Appropriate & Unsatisfied & No \\
\hline 9 & 50 & No & Inappropriate & Unsatisfied & No \\
\hline 10 & 47 & No & Appropriate & Satisfied & No \\
\hline 11 & 16 & No & Inappropriate & Satisfied & Yes \\
\hline 12 & 40 & No & Appropriate & Satisfied & Yes \\
\hline 13 & 52 & No & Inappropriate & Satisfied & Yes \\
\hline 14 & 48 & No & Appropriate & Unsatisfied & No \\
\hline 15 & 36 & No & Inappropriate & Unsatisfied & No \\
\hline 16 & 48 & No & Inappropriate & Unsatisfied & No \\
\hline 17 & 48 & No & Appropriate & Unsatisfied & No \\
\hline 18 & 33 & No & Appropriate & Satisfied & No \\
\hline Total & Average & Yes 0 & Appropriate9 & Satisfied6 & Yes6 \\
\hline & 45.22 & No 18 & Inappropriate9 & Unsatisfied 12 & No 12 \\
\hline
\end{tabular}

In the follow-up period of 1 to 5 years after whitening, none of the teeth included in the study presented external cervical resorption. The height of the gutta-percha was considered inappropriate in $50 \%$ of the patients but did not present a positive correlation with the color stability in the referred follow-up interval. There was no correlation between the color relapse and the monitoring period or cause of darkening $(\mathrm{p}>0.05)$ as shown in table 4 . There was a positive correlation only between the degree of patient's satisfaction and color stability after whitening treatment $(\mathrm{p}<0.05)$ (Table 4$)$.

Table 4 - Correlations between the factors with color stability by the Spearman's correlation $(p$ « 0.05)

\begin{tabular}{|ccc|}
\hline Factors & \multicolumn{2}{c|}{ Correlations } \\
\hline Color stability x Height of gutta-percha & -0.236 & p-level \\
\hline Color stability x Return interval & -0.161 & 0.346 \\
\hline Color stability x Cause of darkening & -0.057 & 0.523 \\
\hline Color stability x Patient's satisfaction & 0.707 & 0.021 \\
\hline
\end{tabular}

\section{DISCUSSION}

This retrospective observational study evaluated the clinical performance of whitening treatment in nonvital teeth. It is a study which was adequately designed following the Strengthening the Reporting of Observational Studies in Epidemiology (STROBE) statement.

Despite the determination of main factors that can interfere in the stability of the whitening, it is difficult to evaluate dental aesthetics or the effectiveness of intervention, only with professional assessment because it may hide other factors $[17,18]$. Therefore, information obtained from the patients should be supplemented, since that their perceptions of oral health are important in assessing needs and determining outcomes oral health $[19,20]$.

The frequency of patients that did not attend to recall times is a limiting factor for longitudinal and transverse studies [15]. In this study, only 18 patients were evaluated, which characterizes one of its limitations. However, this limitation does not affect 
the validity of the findings, since factors that compromise the stability of whitening treatment can be evaluated in a reduced period, and clinically relevant factors might be suggested. In addition, few studies have evaluated the clinical performance of whitening treatment and its correlation with the patient satisfaction/perception with different samples and results [17,18,20-23].

Most of the teeth presented color change regardless of the follow-up interval assessed and the cause of the darkening (Table 3), which confirms the findings in other studies $[13,15]$. In the study by Deliperi and Bardwell [14], when assessing the efficacy of whitening in 26 non-vital teeth, color relapse was observed in 13 teeth after two years. Amato and colleagues [13] showed that 22 of the 35 cases $(62.9 \%)$ remained stable after 16 years, with the color similar to that of adjacent teeth, while 13 cases (37.1\%) presented color change. Abbott and Heah [15], when analyzing 255 teeth, reported that some of the evaluated teeth had color relapse after 2-5 years and this was possibly related to the failure of the restoration. Recently, other authors [24] observed similar effectiveness of two whitening techniques in 18 patients after two weeks, and after one year, the authors noted that there was no color relapse.

The color relapse rate in bleached and endodontically treated teeth is relatively high, and the mechanism has not yet been fully elucidated. In some studies, color relapse is reported after two years [13,14], others report that recurrence occurs only from the fifth year $[15,25,26]$. In cases where no color relapse was detected after dental whitening, patients considered the treatment satisfactory and the color acceptable (Table 3 ). Previous studies $[17,20]$ had shown that the presence of tooth discoloration could produce impact in the oral health-related quality of life, with individuals reporting problems to smile or being unsatisfied with the appearance of their teeth. This may be related to the average age of patients. It was reported that the elderly noticed less impact regarding aesthetics than younger ones [27]. Thus, they might favor the observation of a "negative" impact of the whitening treatment. This could also explain the dissatisfaction of the majority of patients in the present study. If the study patients were older, perhaps the results could be different.

In this study, the distribution was 14 female and 4 male patients, which is in accordance with the demographic distribution of patients who require endodontic treatment, being 2:1 for women and men, respectively $[28,29]$. The results showed that 10 of the 14 women evaluated, presented tooth discoloration due to iatrogenic endodontic treatment. This finding confirms that incomplete removal of obturator materials from the pulp chamber might lead to the darkening of endodontically treated teeth [30-33]. Such materials, when in direct contact with dentin, penetrate into dentin tubules altering their chemical composition and affecting their optical properties [34,35].

In other studies, trauma was considered the most common cause of tooth discoloration $[13,15]$. It was also verified that the distribution of darkened teeth found in this study is consistent with the location of teeth reported in dental trauma studies and requiring intracoronal whitening $[13,15,24,36]$, with a higher prevalence in maxillary central incisors.

Cases of external cervical resorption might be directly related to the use of highly concentrated whitening agents for more extended periods, trauma or heat application (thermo-catalytic technique) [37-42]. The etiology of resorption has not yet been fully explained, and its reported incidence ranges from $1 \%$ to $13 \%$ [40-42]. Radiographic assessment did not show any process of radicular resorption regardless of the whitening technique (inside-outside), as indicated in previous studies by Amato and colleagues [13], Abbot and Heah [15], Kim and colleagues [43], Lise and colleagues [24] and Reston and colleagues [44], who 
performed evaluations after 1 to 16 years of whitening.

The results of this study reinforce that intracoronal whitening is a straightforward and fast esthetic approach, with visible and satisfactory outcomes over a short period, resulting in the improvement in aesthetics, with minimal side effects. No correlation has been found in this study between some of the determinants of the success of whitening treatment in devitalized teeth. Therefore, this research may be helpful as the basis for a prospective longitudinal study with a more extended evaluation periods. Also, future studies should associate the whitening to changes in quality of life of patients, which is an essential part of the overall evaluation of treatment.

\section{CONCLUSIONS}

Based on the findings on this retrospective observational study, it can be concluded that:

1. Color changes after whitening influenced patient's satisfaction.

2. There was no correlation among the color relapse and height of gutta-percha, return interval or cause of darkening.

\section{REFERENCES}

1. Tin-0o MM, Saddki N, Hassan N. Factors influencing patient satisfaction with dental appearance and treatments they desire to improve aesthetics. BMC Oral Health. 2011Feb 23;11:6. doi: 10.1186/1472-6831-11-6.

2. Montero J,Gómez-Polo C, Santos JA, Portillo M, Lorenzo MC, Albaladejo A. Contributions of dental colour to the physical attractiveness stereotype.J Oral Rehabil. 20140ct,41(10):768-82. doi: 10.1111/joor.12194.

3. Al-ZareaBK. Satisfaction with appearance and the desired treatment to improve aesthetics. Int J Dent. 2013;2013:912368. doi: 10.1155/2013/912368.

4. Correia AMO, Melo BED, Cedraz JSB, Rocha DM, Santos NB, Fragoso LSM. Influence of solutions with pigmentation potential on tooth color after bleaching using 22\% carbamide peroxide. Biosci J. 2017;33(4):1106-12.

5. Plotino G, Buono L, Grande NM, Pameijer CH, SommaF.Nonvital tooth bleaching: a review of the literature and clinical procedures. JEndod. 2008 Apr;34(4):394-407. doi: 10.1016/j.joen.2007.12.020.

6. Nahsan FP,Mondelli RF,Franco EB, Naufel FS, Ueda JK, Schmitt V, Baseggio W. Clinical strategies for esthetic excellence in anterior tooth restorations: understanding color and composite resin selection. J Appl Oral Sci. 2012:20(2):151-6.
7. Beddis HP,Nixon PJ. Layering composites for ultimate aesthetics in direct restorations. Dent Update. 2012;39(9):630-2, 634-6. Doi:1012968/ denu.2012.39.9.630.

8. Paolone G, Saracinelli M, Devoto W, Putignano A. Esthetic direct restorations in endodontically treated anterior teeth. Eur J Esthet Dent. 2013;8(1):44-67.

9. Settembrini L, Gultz J, Kaim J, Scherer W. A technique for bleaching nonvital teeth: inside/outside bleaching. J Am Dent Assoc. 1997;128(9):1283-4.

10. Nutting EB, Poe GS. A new combination for bleaching teeth.J Calif Dent Assoc. 1963;31(9):289-91.

11. Redha 0, Strange A, Maeva A, Sambrook R, Mordan N, McDonald A, Bozec L. Impact of carbamide peroxide whitening agent on dentinal collagen. JDent Res.2019 Apr;98(4):443-449. doi:10.1177/0022034518822826.

12. Cakir FY, Korkmaz Y, FiratE, Oztas SS, Gurgan S. Chemical analysis of enamel and dentin following the application of three differentat-home bleaching systems. Oper Dent.2011 Sep-0ct;36(5):529-36. doi:10.2341/11-050-L.

13. Amato M, Scaravilli MS, Farella M, Riccitiello F. Bleaching teeth treated endodontically: Iong-term evaluation of a case series. JEndod. 2006;32(4):376-8. doi: 10.1016/j.joen.2005.08.018.

14. Deliperi S, Bardwell DN. Two-year clinical evaluation of nonvital tooth whitening and resin composite restorations. J Esthet Restor Dent. 2005;17(6):369-78.

15. AbbottP,Heah SY.Internal bleaching of teeth: an analysis of 255 teeth. Aust Dent J.2009 Dec;54(4):326-33. doi: 10.1111/j.1834-7819.2009.01158.x.

16. Howell, RA. The prognosis of bleached root-filled teeth. IntEndod J. 1981;14(1):22-6. doi:10.1111/1.1365-2591.1981.tb01055.x.

17. Meireles SS, Goettems ML, Dantas RV, Bona ÁD, Santos IS, Demarco FF. Changes in oral health related quality of life after dental bleaching in a doubleblind randomized clinical trial. J Dent. 2014 Feb;42(2):114-21. doi:10.1016/j. jdent.2013.11.022.

18. Maghaireh GA, Alzraikat $H$, Taha NA. Satisfaction with dental appearance and attitude toward improving dental esthetics among patients attending a dental teaching center. J Contemp Dent Pract. 2016;17(1):16-21. doi:10.5005/ jp-journals-10024-1796.

19. BuckD, Newton JT. Non-clinical outcome measures in dentistry: publishing trends 1988-98. Community Dent Oral Epidemiol. 2001;29(1):2-8.

20. Bersezio C, Ledezma P,Estay J, Mayer C, Rivera 0, Fernandéz. Color regression and maintenance effect of intracoronal whitening on the quality of life: RCT-a one-year follow-up study. Oper Dent. 2019 Jan/Feb;44(1):24-33. doi: 10.2341/17288-C.

21. Salem YM, Osman YI. The effect of in-office vital bleaching and patient perception of the shade change. SADJ. 2011;66(2):70,72-6.

22. Bernardon JK, FerrariP,Baratieri LN, Rauber GB. Comparison of treatment time versus patient satisfaction in at-home and in-office tooth bleachingh therapy. $\mathrm{J}$ ProsthetDent. 2015 Dec;114(6):826-30. doi:10.1016/jprosdent.2015.05.014.

23. Soares KDA, Nascimento-Júnior EM, Peixoto AC, Faria-e-Silva AL Changes in dental esthetic perceptions of patients subjected to in-office tooth bleaching. BrazDent Sci. 2018;21(2):230-36. doi:10.14295/bds.2018.v21i21559.

24. Lise DP,Siedschlag G, Bernardon JK, Baratieri LN. Randomized clinical trial of 2 nonvital tooth bleaching techniques: a1-year follow-up. JProsthet Dent. 2018 Jan;119(1):53-9. doi: 10.1016/.jprosdent.2017.03.004.

25. Feiglin, B. A6-year recall study of clinically chemically bleached teeth. Oral Surg Oral Med Oral Pathol. 1987;63(5):610-3.

26. Glockner K, Hulla H, Ebeleseder K, Stadtler P.Five-year follow-up of internal bleaching. BrazDent J. 1999;10(2):105-10. 
27. McCarney R, Warner J, lliffe S, Haselen RV, Griffin M, Fisher P.The Hawthorne effect: a randomised, controlled trial. BMC Med Res Methodol. 2007;7:30. doi: 10.1186/1471-2288-7-30.

28. AbbottPV. Analysis of a referral-based endodontic practice: Part 1. Demographic data and reasons for referral. JEndod. 1994;20(2):93-6. Doi: 10.1016/S0099-2399(06)81190-8.

29. Waldman HB, Feigen ME. Endodontists in a period of improving dental economics and changing realities of practice. JEndod. 1990;16(4):179-81. doi: 10.1016/S0099-2399(06)81967-9

30. Burgt TPVD, Plasschaert AJ. Bleaching of tooth discoloration caused by endodontic sealers. JEndod. 1986;12(6):231-4. doi:101016/S00992399(86)80253-9.

31. Burgt TPVD, Mullaney TP,Plasschaert AJ. Tooth discoloration induced by endodontic sealers. Oral Surg Oral Med Oral Pathol. 1986;61(1):84-9. doi: 10.1016/0030-4220(86)90208-2.

32. Gurel MA, Kivanc BH, Ekici A, Alaçam T.Evaluation of crown discoloration induced by endodontic sealers and colour change ratio determination after bleaching. Aust Endod J.2016 Dec;42(3):119-123. doi:10.1111/aej.12147.

33. Jang JH, Kang M, Ahn S, Kim S, Kim W, Kim Y, KimE. Tooth discoloration after the use of new pozzolan cement (Endocem) and mineral trioxide aggregate and the effects of internal bleaching. J Endod. 2013 Dec;39(12):1598-602. doi: 10.1016/j.joen.2013.08.035.

34. Parsons JR, Walton RE, Ricks-Williamson L. In vitro longitudinal assessment of coronal discoloration from endodontic sealers. J Endod. 2001;27(11):699-702. doi:101097/00004770-200111000-00012
35. Wei J, Wang Y,Li Q. Spectroradiometric and chemical analysis of severely discolored endodontically treated teeth. Oper Dent. 2016 Jul-Aug;41(4):370-8. doi: 10.2341/15-243-C.

36. Bastone EB, Freer TJ,McNamara JR. Epidemiology of dental trauma: a review of the literature. AustDent J. 2000;45(1):2-9. doi:10.1111//.1834-7819.2000. tb00234.x.

37. Friedman S. Internal bleaching: long-term outcomes and complications. J Am Dent Assoc. 1997;128:51S-55S. doi:10.14219/jadaarchive.1997.0425.

38. Attin T,Paque F,Ajam F,Lennon AM. Review of the current status of tooth whitening with the walking bleach technique. Int Endod J.2003 May;36(5):31329. doi: 10.1046/j.1365-2591.2003.00667.x.

39. Madison S, Walton R. Cervical root resorption following bleaching of endodontically treated teeth. JEndod. 1990;16(12):570-4.

40. Latcham NL. Postbleaching cervical resorption. JEndod. 1986;12(6):262-4.

41. Latcham NL. Management of a patient with severe postbleaching cervical resorption. A clinical report. J Prosthet Dent. 1991;65(5):603-5. doi: 10.1016/0022-3913(91)90190-8.

42. Harrington GW, Natkin E. External resorption associated with bleaching of pulpless teeth. J Endod. 1979;5(11):344-8. doi:101016/S0099-2399(79)80091-6.

43. Kim Y,LeeCY,KimE, Roh BD. Invasive cervical resorption: treatment challenges. Restor DentEndod. 2012 Nov;37(4):228-31. doi:10.5395/ rde.2012.37.4.228.

44. Reston EG, Bueno R, Closs LQ, Zettermann J. Fifteen-year clinical follow-up of restoration of extensive cervical resorption in a maxillary central incisor. Oper Dent. 2017;42(2):E55-E58.Doi:10.2341/15-131-S.

\section{Felipe de Souza Matos}

\section{(Corresponding address)}

Department of Restorative Dentistry, Endodontic Division, Institute of Science and

Technology, São Paulo State University (Unesp), Av. Eng. Francisco José Longo, 777.

São José dos Campos, SP, Brazil.

ZIPCODE: 12245000

Date submitted: 2019 Jun 18

E-mail: felipe_smatos@hotmail.com 